\title{
The Role of Muhammadiyah in Preventing Islamic Radicalism in Banten (2000-2017)
}

\author{
Asrori Mukhtarom \\ Muhammadiyah University of \\ Tangerang \\ asrorimukhtarom84@gmail.com
}

\author{
Priyo Susilo \\ Muhammadiyah University of \\ Tangerang
}

\author{
Akhmad Zakky \\ Muhammadiyah University of \\ Tangerang
}

\begin{abstract}
This study examines the role of Muhammadiyah Regional Board of Banten in preventing Islamic radicalism. Banten province is a place where Islamic radicalism has a long history, from NII (Indonesia Islamic Nation), a mastermind in a bomb attack, and even the executant in a suicide bombing. It shows Banten has a great potential in producing any Islamic radicalism movement, and the responsibility on this potential not only in government hand but also in a social community or Islamic community organizations. The study argues that Muhammadiyah, as one of largest Islamic mass organizations in Indonesia has a significant contribution in preventing Islamic radicalism by doing moderation ways as PWM (Muhammadiyah Regional Board) of Banten has been doing in Banten. Muhammadiyah in Banten has been preventing radicalism, among others by way of educational institutions under this organization and da'wah activities. These activities show that Muhammadiyah, particularly in Banten, not only has done their job in protecting the society from any Islamic radicalism movements, but also made a new discourse about how to face radicalism.
\end{abstract}

Keywords: islamic radicalism, muhammadiyah, banten, discourse.

\section{INTRODUCTION}

The issue of Islamic radicalism in Indonesia reappear, at least, after Bali bombing in 2002. The bomb attack in Bali became one of the indications, and of course the alert, of the return of radical Islamic groups which during the New Order has been repressed by the state. Since then Indonesia began to be seen as a country that has the potential for the birth and reappearance of radical Islamic groups. International Crisis Group noted that after Bali bombing, Islamic radicalism in Indonesia had putted international attention. In developing their movements, the extremists had been trying to find many ways to regroup and building new alliances [1]. It shows the effort of Islamic radical group to survive and keep moving on their activities. In other hand, this phenomenon is a challenge, not only for police but also for all parties in Indonesia to face and prevent all these radical movements.

The Islamic radical notions and movements in Indonesia is not a new thing. The roots of this notions and movements can be traced back to the New Order period. Islamic radicalism emerged and disseminated, one of them, from so-called multidimensional crisis in 1997 when Soeharto's regime could not handle economic and political crisis. In contemporary Indonesia, this crisis triggered the birth of Islamic radical groups. In addition, Zada sees the fall of Soeharto provides a way for Islamic radical groups to grow up and accelerate their movements [2]. It looked the Islamic radical groups had met a good moment to build a base in society and spread their notions.

Furthermore, in its development, the Islamic radical groups began to conduct terror activities by conducting bombings and suicide bombings, then allegations arise that the groups that committed the terror is affiliated or declared themselves affiliated with al Qaeda. Muzakki depicting the relation of al Qaeda with radical groups in Southeast Asia. Al Qaeda, which is widely known as number one Islamic terrorist group in the world has links with other Islamic radical groups in region, and said to be responsible from the bomb attack in Southeast Asia, such as in Indonesia, Malaysia, Philippine, and Singapore [3].

To see the contemporary radicalism in Indonesia, Fealy and Borgu noted local and international factors as cause of emerging and expansion on the radicalism notion. Most radical Muslims believe Islam in Indonesia has been oppressed and marginalized in political, religious, and economic elements. Meanwhile, from the external factors have stronger influence; the internationalization of jihad that culminating in antiSoviet war in Afganistan in 1980s. These factors have increased the spirit of jihad, not only in Middle East but also in Indonesia, and sometimes it can be seen as a solidarity among Muslims [4].

Muhammadiyah sees the program called by the Indonesian government as a deradicalization program will not be able to stem the movement or notion of any Islamic radicalism in Indonesian society. In view of Muhammadiyah, the deradicalization program run by the government not only cannot solve the problem of Islamic radicalism, but also will bring up to other radicalism among Muslims. Haedar Nasir sees moderation, also called a third way, an alternative solution different from the deradicalism program run by Badan Nasional Penanggulangan Terorisme (National Agency for Counter-Terrorism), and Muhammadiyah believes that moderation is the best way to face and counter radicalism [5]. Din Syamsudin argues that deradicalism will bring up new violence, extremism, or radicalism [6]. At its conclusion, when Indonesian government sees deradicalization as an answer for Islamic radicalism, 
Muhammadiyah offers a different way to face it. For Muhammadiyah, moderation can wipe out the radicalism even to the roots.

The concept of moderation as a middle path offered and run by the Muhammadiyah can be viewed as a contribution of an Islamic mass organization to the state, as well as the form of religious contribution in the fight against radicalism which is often done on the basis of religion. This relationship which was later mentioned by Mas'udi as a mutual relationship between religion and the state of each other; through the universal message of peace existing in religion. Thus, in this social context, religion can show its social function in society [7]. Therefore, by all the arguments above, doing research about Muhammadiyah in Banten and its effort to face and prevent Islamic radicalism in Banten is important. Besides, Banten is a red zone for radicalism activities.

\section{METHOD}

In this research, the researchers used descriptivequalitative method in order to observe the Muhammadiyah's role, especially in Banten, in preventing radicalism in society. There are two sources of data collected in this study: primary and secondary. Primary data obtained from in-depth interview with the parties which are related to the moderation strategy in PWM Banten and observation to many activities undertaken by PWM Banten and all institutions under it. Whereas secondary data is obtained from searches on existing data in the field, including various papers and notes that have relevance to this research.

In this research, the concept of moderation proposed by Muhammadiyah as the main reference in viewing patterns of prevention of Islamic radicalism in Banten. In addition, the application of moderation concepts in the practice level at various institutions under Muhammadiyah regional board of Banten became the data in this study. To analyze the role of PWM Banten in blocking the radical Islamic movement, researchers will use the theory of discourse by Michel Foucault. Foucault sees discourse as a part of the practice of power with the aim of attaching meaning to human experience. In other words, discourse relates to power, and power is related to knowledge. Thus, the dominant discourse is a representation of dominance and dominant knowledge [8]. Meanwhile, according to Mills, Discourse in the Foucault's sense can be understood both the means of oppressing and the means of resistance [9].

This theory is considered appropriate because Muhammadiyah's attempts to use the moderation strategy to prevent radical action not only as an organizational program, but the researchers see this as a counter discourse. In addition, what Muhammadiyah did, actually is an attempt to counter the dominant discourse, or becomes a new discourse, that the government has built on radical Islamic movements and how to cope with the deradicalization program.

\section{RESULTS AND DISCUSSION}

In general, the people of Banten can be categorized as devout Muslims. With the spread of thousands pesantren (Islamic Boarding School), it can be said that Islam is close to Banten society. In addition to devout Muslims, long-standing culture in Banten society is agrarian with a high solidarity. In other side, Banten is a place where Islamic radicalism, or the seed and the notion of radicalism, has long history. After the Bali bombings in 2002, Banten became one of the areas in Indonesia that are connected with many acts of radicalism. Some of the perpetrators, often called terrorism, were arrested and even planned or committed to doing terror in Banten. The number of perpetrators who were arrested in Banten, and linked to radicalism put Banten in the red zone category on the map of radicalism in Indonesia. However, seeing the radical Islamic movement in Banten is an important part in looking at the map of the radical Islamic movements of Indonesia as a whole.

In an attempt to counter Islamic radicalism, either the notion or the movement, PWM Banten, as the moderation concept that has been formulated by PP Muhammadiyah (Central Board of Muhammadiyah), applies the concept of moderation in various fields. The idea of moderation has been internalized in various forms in all institutions under PWM Banten. PWM Banten as a part of society has to contribute to facing the problem of Islamic radicalism. Syamsudin as a chairman of PWM Banten provides some important points that can be used as a reference in the face of radicalism; PWM Banten expressly rejects all acts of violence in the name of religion, cooperates with MUI (Indonesian Ulama Council) in facing Islamism radicalism and through education [10]. In addition, Zakaria Syafei, secretary of PWM Banten, also stated almost the same thing; in order to prevent radicalism, the path taken is moderation, through cooperation with other mass organizations, and introducing the face of a wasathiyah (moderate) Islam to society [11]. These statements seems like a summary of PWM Banten action to face any radicalism issues in Banten.

In the field of education, the concept of moderation that has been campaigning by PP Muhammadiyah is applied in the teaching process of educational institutions under the auspices of PWM Banten, either at the elementary school, junior high school senior high school, or colleges. Through the subject matters, moderation as a middle path in the face of radicalism is inserted in the classroom. Even in the process of learning in college, through AIK (Al Islam and Kemuhammadiyahan) courses students are directly and indirectly given an understanding of how Islam is actually a religion filled with messages of peace and does not teach violent ways in any form. College is, however, an educational institution which is the most infiltrated by radical ideology. Therefore, AIKA course is intentionally arranged with the intention of directing students to 
become human beings who can do good to all people and even be tolerant to non-Muslims [12]. The preparation of the subject matters for AIKA seems to be responding to the phenomenon of radicalism that most targeting students in college.

In the field of $d a^{\prime} w a h$, PWM Banten also equips the preachers with the concept of moderation. Therefore, every religious discussion activity that is conducted in PWM Banten becomes part of dissemination of moderation way in preventing Islamic radicalism. The field of da'wah actually has a broad reach in spreading the idea of moderation because people who usually follow the discussion consist of various ages, and performed in many places. Thus, the field of $d a$ 'wah is very important to note in dissemination in moderation way.

By practicing moderation in responding to radicalism in society, PWM Banten is actually building a new discourse on how to understand the actions of radicalism. If the government with the concept of deradicalization means making a discourse about what terrorism is, then the ways of moderation also ultimately become a new discourse about what is radicalism. Applying moderation in the region of Banten is important because Banten is a dangerous area for any radicalism activities.

\section{CONCLUSION}

Muhammadiyah is one of the Islamic mass organizations in Indonesia which since 1912 has engaged in da'wah, education, and many social activities. Muhammadiyah is often referred to as one of the largest moderate Islamic mass organizations in Indonesia, and well known as an Islamic organization which have been doing da'wah peacefully. As a moderate Islamic organization, Muhammadiyah formulated its own way to block all forms of radical ideas and actions. Muhammadiyah then offered the concept of moderation to overcome all radical Islamic movements in Indonesia, when PWM Banten applies moderation in Banten, it means that PWM Banten builds a new discourse on Islamic radicalism in society. Seeing the contribution of PWM Banten is important since Banten become one of the many places found by the perpetrators of radicalism. Then PWM Banten has been facing and preventing radicalism by disseminating moderation ideas by way of their activities; either in social, education, and da'wah activities.

\section{REFERENCES}

[1] International Crisis Group. How Indonesian Extremist Regroup, Asia Report No. 228, 16 July 2012.

[2] Zada, Khamami. Islam Radikal: Pergulatan Ormas-ormas Islam Garis Keras di Indonesia. Jakarta: Teraju, 2002.

[3] Muzakki, Akhmad. The Roots, Strategies, and Popular Perception of Islamic Radicalism in Indonesia. Journal of Indonesian Islam, Vol. 8 No. 1, June 2014: 1-22.

[4] Fealy, Greg, and Aldo Borgu. Local Jihad: Radical Islam and Terrorism in Indonesia. Barton: The Australian Strategic Policy Institute, 2005.

[5] Nasir, Haidar. "Moderasi Sebagai Jalan Ketiga."SuaraMuhammadiyah. (16-31 March 2016): 16-18.

[6] Syamsudin, Din. "Deradikalisme Memunculkan Ekstrimisme Baru.” SuaraMuhammadiyah. (16-31 March 2016): 14-15.

[7] Mas'udi, Masdar F. "Islam and The State: The Social Justice Perspective." Islam In Contention: Rethinking Islam and The State in Indonesia. Ed. Ota Atsushi, Okamoto Masaaki, and Ahmad Suaedy. Jakarta: Wahid Institute-CSEAS-CAPAS, 2010. 15-25.

[8] Foucault, Michel. TheArcheologyofKnowledge. London: Routledge, 1989.

[9] Mills, Sara. MichelFoucault. London: Routledge, 2003.

[10] Syamsudin. Telephone interview. 19 May 2018.

[11] Syafei, Zakariya. Telephone interview. 19 May 2018.

[12] Tim Pedoman Pendidikan Al-Islam dan Kemuhammadiyahan Majelis Pendidikan Tinggi PP Muhammadiyah. Buku Pedoman Pendidikan Al-Islam dan Kemuhammadiyahan Perguruan Tinggi Muhammadiyah. Yogyakarta: Majelis Pendidikan Tinggi Pimpinan Pusat Muhammadiyah. 2013. 